\title{
Advanced low-temperature solid oxide fuel cells based on a built-in electric field
}

\author{
Yuzheng Lu' ${ }^{1}$, Bin $\mathrm{Zhu}^{2,3}$, Jing Shi ${ }^{4}$, Sining Yun ${ }^{5,6}$ \\ 1School of Electronic Engineering, Nanjing Xiaozhuang University, Nanjing 211171, Jiangsu, China. \\ ${ }^{2}$ Jiangsu Provincial Key Laboratory of Solar Energy Science and Technology/Energy Storage Joint Research Center, School of \\ Energy and Environment, Southeast University, Nanjing 210096, Jiangsu, China. \\ ${ }^{3}$ State Key Laboratory of Multiphase Flow in Power Engineering, Xi'an Jiaotong University, Xi'an 710049, Shannxi, China. \\ ${ }^{4}$ Department of Physics, Xi'an Jiaotong University City College, Xi'an 710018, Shannxi, China. \\ ${ }^{5}$ Functional Materials Laboratory (FML), School of Materials Science and Engineering, Xi'an University of Architecture and \\ Technology, Xi'an 710055, Shannxi, China. \\ ${ }^{6}$ Qinghai Building and Materials Research Academy Co., Ltd, the Key Lab of Plateau Building and Eco-community in Qinghai, \\ Xining, Qinghai 810000, China.
}

Correspondence to: Prof. Bin Zhu, School of Energy and Environment, Southeast University, No. 2 Si Pai Lou, Nanjing 210096, Jiangsu, China. E-mail: zhu-bin@seu.edu.cn; Prof. Sining Yun, School of Materials Science and Engineering, Xi'an University of Architecture and Technology, No.13 Yanta Road, Xi'an 710055, Shannxi, China. E-mail: yunsining@xauat.edu.cn

How to cite this article: Lu Y, Zhu B, Shi J, Yun S. Advanced low-temperature solid oxide fuel cells based on a built-in electric field. Energy Mater 2021;1:100007. https://dx.doi.org/10.20517/energymater.2021.06

Received: 1 Sep 2021 First Decision: 27 Sep 2021 Revised: 15 Oct 2021 Accepted: 20 Oct 2021 Published: 30 Oct 2021

Academic Editors: Yuping Wu, Wei Tang Copy Editor: Yue-Yue Zhang Production Editor: Yue-Yue Zhang

Solid oxide fuel cells (SOFCs) show considerable promise for meeting the current ever-increasing energy demand and environmental sustainability requirements as a result of their high efficiency and low environmental impact. To enable high ionic conductivity, SOFCs are often required to operate at high temperature, which in turn results in high costs ${ }^{[1]}$. Therefore, lowering the operational temperatures has become a major priority in SOFC research and development ${ }^{[2]}$. According to the traditional concepts of SOFCs, single semiconductor materials are usually considered as electrolyte membrane due to their higher ionic conductivity, with heterostructures constructed from different semiconductor materials having never been considered. Recently, Meng et al. ${ }^{[3]}$ made an important breakthrough in low-temperature SOFCs by introducing semiconductor heterojunction membranes to function alternatively as electrolytes with better performance. This novel fuel cell design is known as a semiconductor-ionic membrane fuel cell (SIMFC) ${ }^{[3-5]}$. Zhang et al. ${ }^{[6]}$, Nie et al. ${ }^{[7]}$, Deng et al. ${ }^{[8]}$, Mushtaq et al. ${ }^{[0]}$, and Afzal ${ }^{[10]}$ used semiconductor materials, including $\mathrm{Ni}_{0.8} \mathrm{Co}_{0.15} \mathrm{Al}_{0.05} \mathrm{LiO}_{2-\delta}^{[6]}, \mathrm{La}_{0.6} \mathrm{Sr}_{0.4} \mathrm{Co}_{0.2} \mathrm{Fe}_{0.8} \mathrm{O}_{3-\delta}{ }^{[7]}, \mathrm{Sr}_{2} \mathrm{Fe}_{1.5} \mathrm{Mo}_{0.5} \mathrm{O}_{6-\delta}{ }^{[8]}, \mathrm{SrFe}_{0.75} \mathrm{Ti}_{0.25} \mathrm{O}_{3-\delta}{ }^{[9]}$, 
$\mathrm{Ba}_{0.5} \mathrm{Sr}_{0.5} \mathrm{Co}_{0.8} \mathrm{Fe}_{0.2} \mathrm{O}_{3-\delta}[10], \mathrm{ZnO}^{[11]}, \mathrm{CeO}_{2-\delta}{ }^{[12]}, \mathrm{SrTiO}_{3}^{[13]}$ and $\mathrm{Ba}_{0.5} \mathrm{Sr}_{0.5} \mathrm{Co}_{0.1} \mathrm{Fe}_{0.7} \mathrm{Zr}_{0.1} \mathrm{Y}_{0.1} \mathrm{O}_{3-\delta}$ (BSCFZY) $)^{[14]}$, to construct a semiconductor membrane (SM) with enhanced ion conduction while electron conduction is blocked via the principles of a semiconductor heterojunction ${ }^{[15-17]}$. The SM can be a composite made by a semiconductor with an ionic conductor material, e.g., Sm-doped ceria, or a semiconductor alone, e.g., $\mathrm{CeO}_{2-\delta}{ }_{-\delta 12]}^{[12]} \mathrm{SrTiO}_{3}{ }^{[13]}$ or $\mathrm{BSCFZY}^{[14]}$, while the traditional SOFC electrolyte component is made using a pure ionic conductor.

Recently, Wang et al. ${ }^{[18]}$ reported a $3 \mathrm{C}-\mathrm{SiC}$, which was tuned for protonic conducting properties via the construction of an n-p heterostructure composite with $\mathrm{Na}_{0.6} \mathrm{CoO}_{2}$, exhibiting an ionic conductivity of $0.12 \mathrm{~S} \mathrm{~cm}^{-1}$ at $550{ }^{\circ} \mathrm{C}$. Lu et al.$^{[19]}$ reviewed recent progress in lowering the temperature of SOFCs by using semiconductor-ionic conductor nanomaterials. The development in the application of nanostructured pure ionic conductors, semiconductors and their nanocomposites as membranes is highlighted in this review. $\mathrm{Xu}$ et al ${ }^{[20]}$ reported a SIMFC using a composite of $\mathrm{Ba}-\mathrm{Co}-\mathrm{Ce}-\mathrm{Y}-\mathrm{O}$ and $\mathrm{CeO}_{2}$, reaching a remarkable peak power density of $1140 \mathrm{~mW} \cdot \mathrm{cm}^{-2}$ at $550{ }^{\circ} \mathrm{C}$. Zhu et al. ${ }^{[21]}$ produced a nanoscale perspective of solid oxide and semiconductor membrane fuel cells from materials to technology. They discussed the nanoscale electrochemical phenomena of SIMFCs. Different from the traditional concept where semiconductor materials are widely used in photoelectric conversion and photocatalysis ${ }^{[22]}$, they also applied them to replace the electrolytes in fuel cells.

It is well known that semiconductor materials have already been successful in photovoltaic cells based on a built-in electric field (BIEF ${ }^{[23]}$. Generally, when $\mathrm{p}$ - and $\mathrm{n}$-type semiconductors are contacted, the redistribution of charges at the interface constitutes a space-charge region with the BIEF pointing from the $\mathrm{n}$ - to $\mathrm{p}$-type region ${ }^{[24]}$. The BIEF is also applied in lithium-ion batteries. Qiao et al. ${ }^{[25]}$ demonstrated a BIEF to reduce the space charge layer formation and boost lithium-ion transport in all-solid-state lithium-ion batteries by an in-situ differential phase contrast scanning transmission electron microscopy technique and finite element method simulations.

Most importantly, Zhang et al..$^{[6]}$, Nie et al.$^{[7]}$, Deng et al..$^{[8]}$, Mushtaq et al..$^{[9]}$, and Afzal ${ }^{[10]}$ successfully applied semiconductor materials in SOFCs by compositing semiconductor and ionic conductor materials to construct SIMFCs with BIEF effects. To understand the principle of SIMFCs, a physical mode based on a BIEF and alignment of the energy band, similar to a perovskite solar cell (PSC), was proposed by Zhu et al. ${ }^{[16]}$. Generally, the perovskite absorbers of a PSC undergo photoexcitation and charge separation under light illumination. The holes move to the metal contact through the hole-transporter materials while electrons are collected by the electron transport layer and move to the fluorine-doped tin dioxide conductive substrate to generate the electricity ${ }^{[2,27]}$. The BIEF in a PSC can effectively prohibit the electrons passing through the device itself. Taking advantage of this concept, Zhu et al. ${ }^{[16]}$ designed a novel fuel cell with a nanocomposite functional layer, where the short circuit issue can be eliminated by a heterojunction structure instead of using the ionic electrolyte layer in SOFCs. The mechanisms of SIMFCs can be explained using the principle of a PSC, as shown in Figure 1A. The charge separation is caused by the well-aligned band positions between the perovskite and electron/hole conducting layers. Inspired by this idea, Zhu et al. ${ }^{[16]}$ constructed an n-type $\mathrm{La}_{0.2} \mathrm{Sr}_{0.25} \mathrm{Ca}_{0.45} \mathrm{TiO}_{3}$ and $\mathrm{p}$-type $\mathrm{La}_{0.6} \mathrm{Sr}_{0.4} \mathrm{Co}_{0.2} \mathrm{Fe}_{0.8} \mathrm{O}_{3-\delta}$ (LSCF) junction, where the electrons cannot pass through the junction. Furthermore, the BIEF in the SIMFC membrane can drive $\mathrm{H}^{+}$or $\mathrm{O}^{2-}$ across the junction, as illustrated in Figure $1 \mathrm{~B}$.

Interestingly, a Schottky junction (SJ) was also found in this all new device, where $\mathrm{Ni}_{0.8} \mathrm{Co}_{0.15} \mathrm{Al}_{0.05} \mathrm{LiO}_{2-\delta}$ (NCAL) is reduced into a Ni-Co alloy at the anode with $\mathrm{H}_{2}$, as indicated in Figure 1B. After the SJ is formed between the anode and electrolyte, it can also inhibit electrons passing through the electrode and SM while 
A

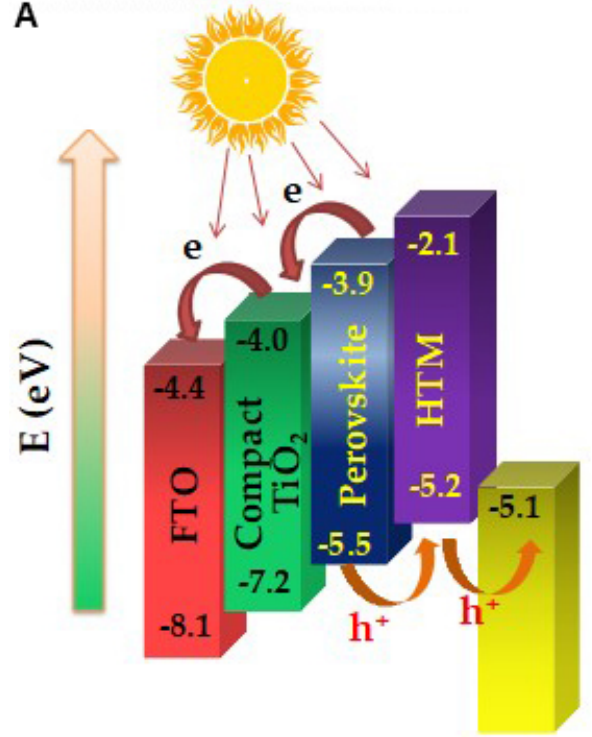

B

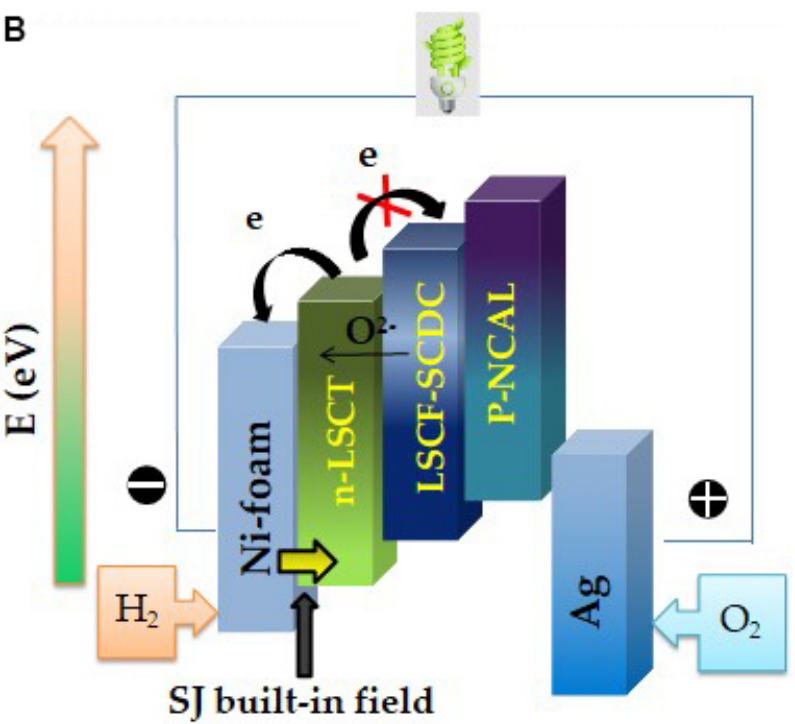

Figure 1. Energy level diagrams of (A) a PSC and (B) the fuel-to-electricity conversion device inspired by the PSC structure ${ }^{[16]}$. LSCT: $\mathrm{La}_{0.2} \mathrm{Sr}_{0.25} \mathrm{Ca}_{0.45} \mathrm{TiO}_{3} ; \mathrm{LSCF}: \mathrm{La}_{0.6} \mathrm{Sr}_{0.4} \mathrm{Co}_{0.2} \mathrm{Fe}_{0.8} \mathrm{O}_{3-\delta} ; \mathrm{SCDC}: \mathrm{Ce}_{0.8} \mathrm{Sm}_{0.05} \mathrm{Ca}_{0.15} \mathrm{O}_{2-\delta} ; \mathrm{NCAL}: \mathrm{Ni}_{0.8} \mathrm{Co}_{0.15} \mathrm{Al}_{0.05} \mathrm{LiO}_{2-\delta} ;$ FTO: fluorine-doped tin oxide; HTM: hole transport materials.

simultaneously enhancing the transportation of $\mathrm{H}^{+}$or $\mathrm{O}^{2-}$ due to the BIEF formation at the interface. The used materials for PSC and SIMFC devices are listed in Table 1. It is true that the junction plays a vital role in blocking electrons crossing over the internal device to avoid short circuiting and also in promoting the ionic transport process.

According to our previous research, the BIEF can be formed by a Schottky heterojunction ${ }^{[24]}$, intrinsicnegative (i-n) heterojunction ${ }^{[12]}$ and $\mathrm{p}-\mathrm{n}$ heterojunction ${ }^{[25]}$. In a Schottky heterojunction, the BIEF can be built up simply at the interface of the metal (electrode) and semiconductor (electrolyte) regions. Yun et al. ${ }^{[28]}$ constructed SJ fuel cells using a p-type semiconductor material, namely, a $\mathrm{LiNi}_{0.85} \mathrm{Co}_{0.15} \mathrm{O}_{2-\delta}$ ( $\mathrm{LCN}$ ) composite with $\mathrm{Ce}_{0.8} \mathrm{Sm}_{0.2} \mathrm{O}_{1.9}-\mathrm{Na}_{2} \mathrm{CO}_{3}$, which exhibited a high power output of $1000 \mathrm{~mW} \mathrm{~cm}^{-2}$ at $550{ }^{\circ} \mathrm{C}$. A thin Nimetal layer originating from reduction of the semiconducting oxide LCN is formed at the $\mathrm{H}_{2}$ side. Therefore, a Ni-metal/p-type LCN-semiconductor SJ is formed that can accelerate ion transport capacity while inhibiting electrons from passing through the junction formed at the anode/semiconductor membrane interface, as shown in Figure 2A.

In order to prove the as-reported SJ, Zhu et al..$^{[29]}$ tested the response current as a function of bias voltage for a half cell with the structure of NCAL-Ni/7LCP-3ZnO at $550{ }^{\circ} \mathrm{C}$ with air and a $\mathrm{H}_{2}$ flow to the NCAL electrode side. The results indicated that an apparent rectification response emerged in the I-V characteristic analogous to the reported I-V response of a $\mathrm{Ni} / \mathrm{ZnO}$-polar contact, illustrating a Schottky contact between the reduced anode and membrane layer. Furthermore, the characterization of semiconductor properties and band structures is very important for SIMFCs based on semiconductor-ionic membranes with BIEF effects, which are very different from conventional SOFCs based on ionic conducting electrolytes. Therefore, various new characterization techniques from semiconductor aspects, like ultraviolet-visible spectroscopy ${ }^{[30]}$, ultraviolet photoelectron spectroscopy ${ }^{[30]}$, Hall coefficient measurement ${ }^{[30]}$, density functional theory calculation $s^{[31]}$ and so on, have been introduced to determine the band structures and prove the BIEF effects on SIMFCs. The different characteristics of SIMFCs compared to SOFCs are obvious because of the use semiconductor-based membranes $v s$. conventional electrolytes. 
Table 1. Comparison of materials used for PSCs and SIMFCs

\begin{tabular}{|c|c|c|c|c|c|}
\hline & Back contact & $\begin{array}{l}\text { Electron transport } \\
\text { layer }\end{array}$ & Functional layer & $\begin{array}{l}\text { Hole transport } \\
\text { layer }\end{array}$ & $\begin{array}{l}\text { Metal } \\
\text { electrode }\end{array}$ \\
\hline PSC & $\begin{array}{l}\text { Fluorine-doped tin dioxide } \\
\text { (FTO) }\end{array}$ & $\mathrm{TiO}_{2}$ & Perovskite absorber & $\begin{array}{l}\text { Hole-transporter } \\
\text { materials }\end{array}$ & $\mathrm{Au}$ \\
\hline SIMFC & Ni foam & $\mathrm{La}_{0.2} \mathrm{Sr}_{0.25} \mathrm{Ca}_{0.45} \mathrm{TiO}_{3}$ & $\begin{array}{l}\mathrm{La}_{0.6} \mathrm{Sr}_{0.4} \mathrm{Co}_{0.2} \mathrm{Fe}_{0.8} \mathrm{O}_{3-8}-\mathrm{Sm} \text { and } \mathrm{Ca} \text { co- } \\
\text { doped } \mathrm{CeO}_{2}\end{array}$ & $\mathrm{Ni}_{0.8} \mathrm{Co}_{0.15} \mathrm{Al}_{0.05} \mathrm{LiO}_{2-\delta}$ & $\mathrm{Ag}$ \\
\hline
\end{tabular}

PSC: Perovskite solar cell; SIMFC: semiconductor-ionic membrane fuel cell.

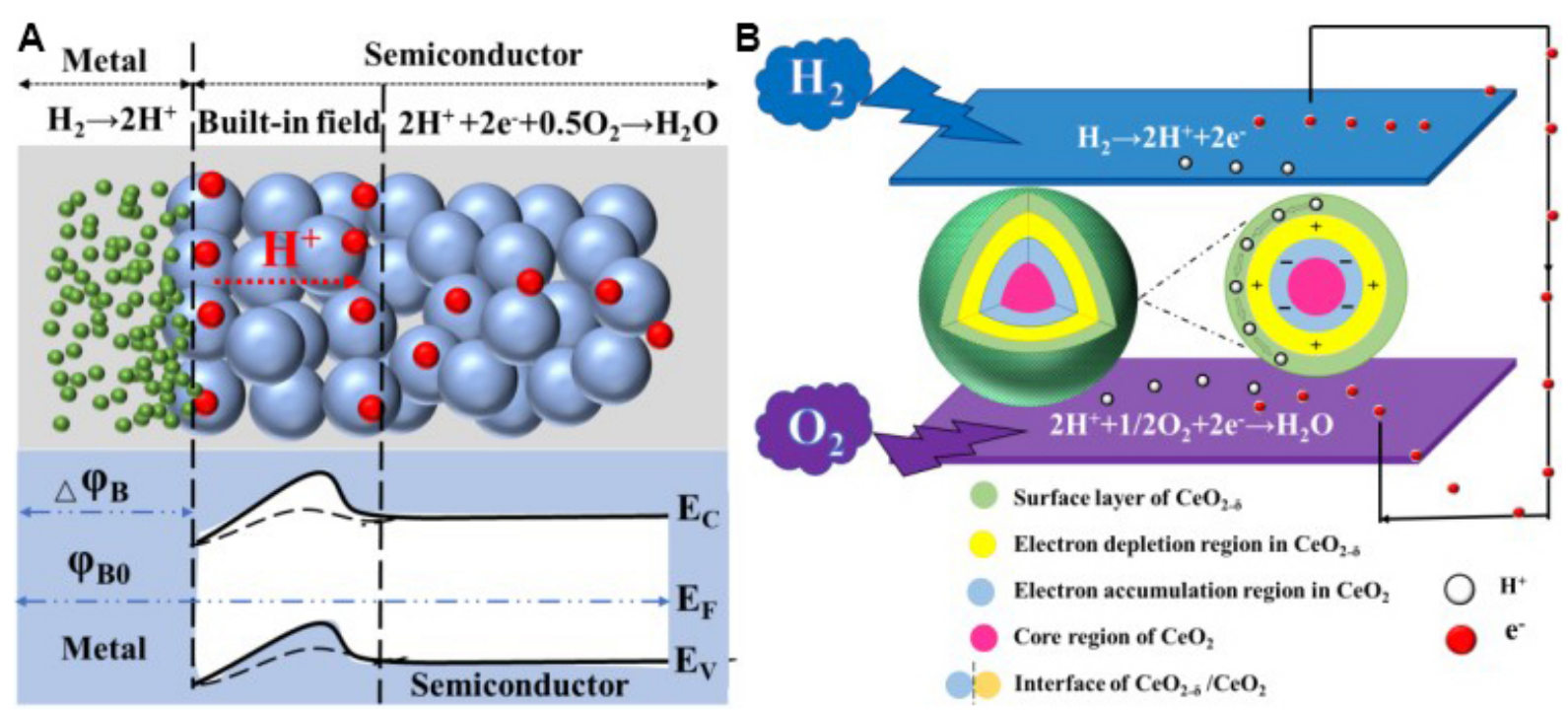

Figure 2. (A) Schottky junction device and energy band diagram for a metal/p-semiconducting oxide interface ${ }^{[28]}$. (B) Charge separation at the interface of $\mathrm{a} \mathrm{CeO}_{2-\delta} / \mathrm{CeO}_{2}$ particle and proton transport to the near-surface layers of the particle ${ }^{[30]}$.

In an $\mathrm{i}$-n heterojunction, an i-n type interface contact is constructed, e.g., a $\mathrm{CeO}_{2} / \mathrm{CeO}_{2-\delta}$ core-shell heterostructure, where $\mathrm{CeO}_{2}$ is an intrinsic $\mathrm{i}$-type semiconductor and $\mathrm{CeO}_{2-\delta}$ is an n-type semiconductor. A charge separation occurs at the $\mathrm{CeO}_{2-\delta} / \mathrm{CeO}_{2}$ interface. The electrons can transfer from the shell to the core while it is forbidden to pass through from the core to the shell. After the $\mathrm{CeO}_{2} / \mathrm{CeO}_{2-\delta}$ core-shell heterostructure forms, an electron depletion region is built on the $\mathrm{CeO}_{2-\delta}$ side at the interface and an electron accumulation region is simultaneously formed on the $\mathrm{CeO}_{2}$ side of the interface. On this basis, the local charge distribution and the electric field or the BIEF are formed among particle surfaces, which stop protons from migrating deep inside the shell to pass through the interface and suppress the bulk infiltration of the surface protons, as shown in Figure $2 \mathrm{~B}$. Benefiting from the BIEF, a "proton shuttle" is constructed in the continuous highly conducting regions formed in the ceria-semiconductor membrane of the SOFC.

To further understand the new mechanism in SIMFCs, Xia et al. ${ }^{[30]}$ constructed a $\mathrm{BaCo}_{0.4} \mathrm{Fe}_{0.4} \mathrm{Zr}_{0.1} \mathrm{Y}_{0.1} \mathrm{O}_{3-\delta}$ (BCFZY)-ZnO p-n heterostructure for low-temperature SOFCs. They found that the as-prepared heterostructure exhibits a hybrid $\mathrm{H}^{+} / \mathrm{O}^{2-}$ conducting capability during fuel cell operation. When two semiconductors with different energy band levels are combined, conduction band offset $(\Delta \mathrm{Ec})$ and valence band offset $(\triangle \mathrm{Ev})$ will be induced, thus forming potential barriers to form the BIEF. To explain its mechanism, a BIEF in the as-prepared BCFZY-ZnO p-n heterostructure was introduced, where the junction prevented the electron passing through and the ionic conductivity can be enhanced by the BIEF, as illustrated by Figure 3. 


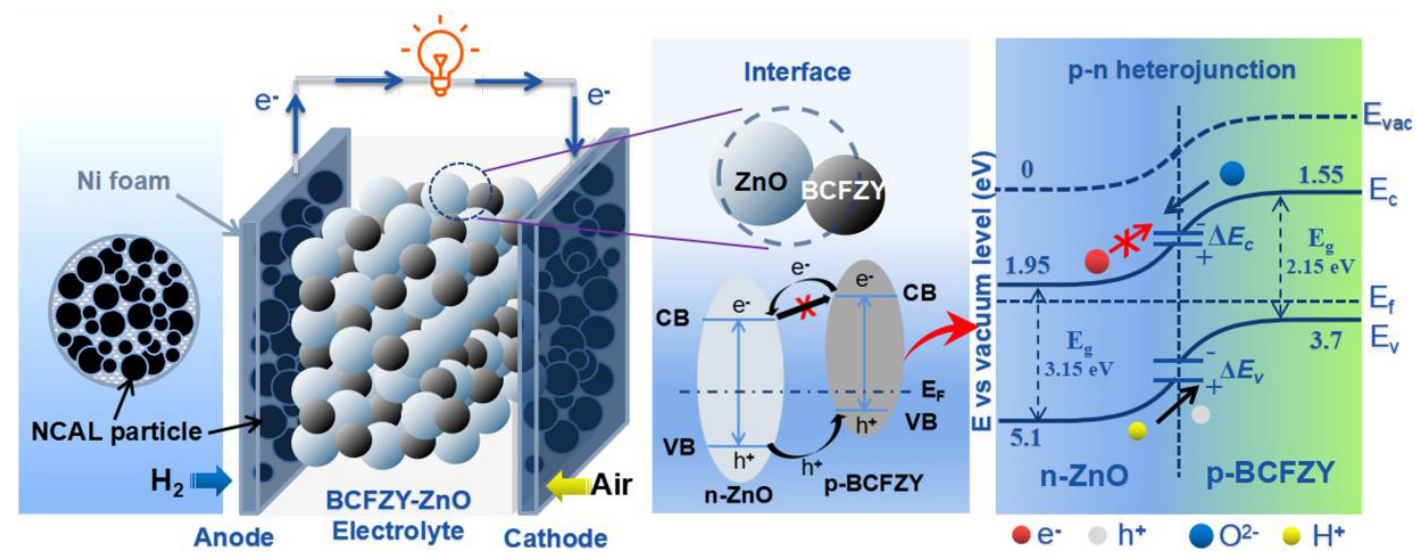

Figure 3. Schematic diagram of a typical $p-n$ heterojunction formed at the heterophasic interface of a p-type (BCFZY)-n-type ( $\mathrm{nnO}$ ) semiconductor membrane and the corresponding energy band alignment mechanism proposed for interpreting the charge separation and ionic transportation process ${ }^{[30]}$. BCFZY: $\mathrm{BaCo}_{0.4} \mathrm{Fe}_{0.4} \mathrm{Zr}_{0.1} \mathrm{Y}_{0.1} \mathrm{O}_{3-\delta} ; \mathrm{NCAL} \mathrm{Ni}_{0.8} \mathrm{Co}_{0.15} \mathrm{Al}_{0.05} \mathrm{LiO}_{2-\delta} ; \mathrm{CB}$ : conduction band; VB: valence band.

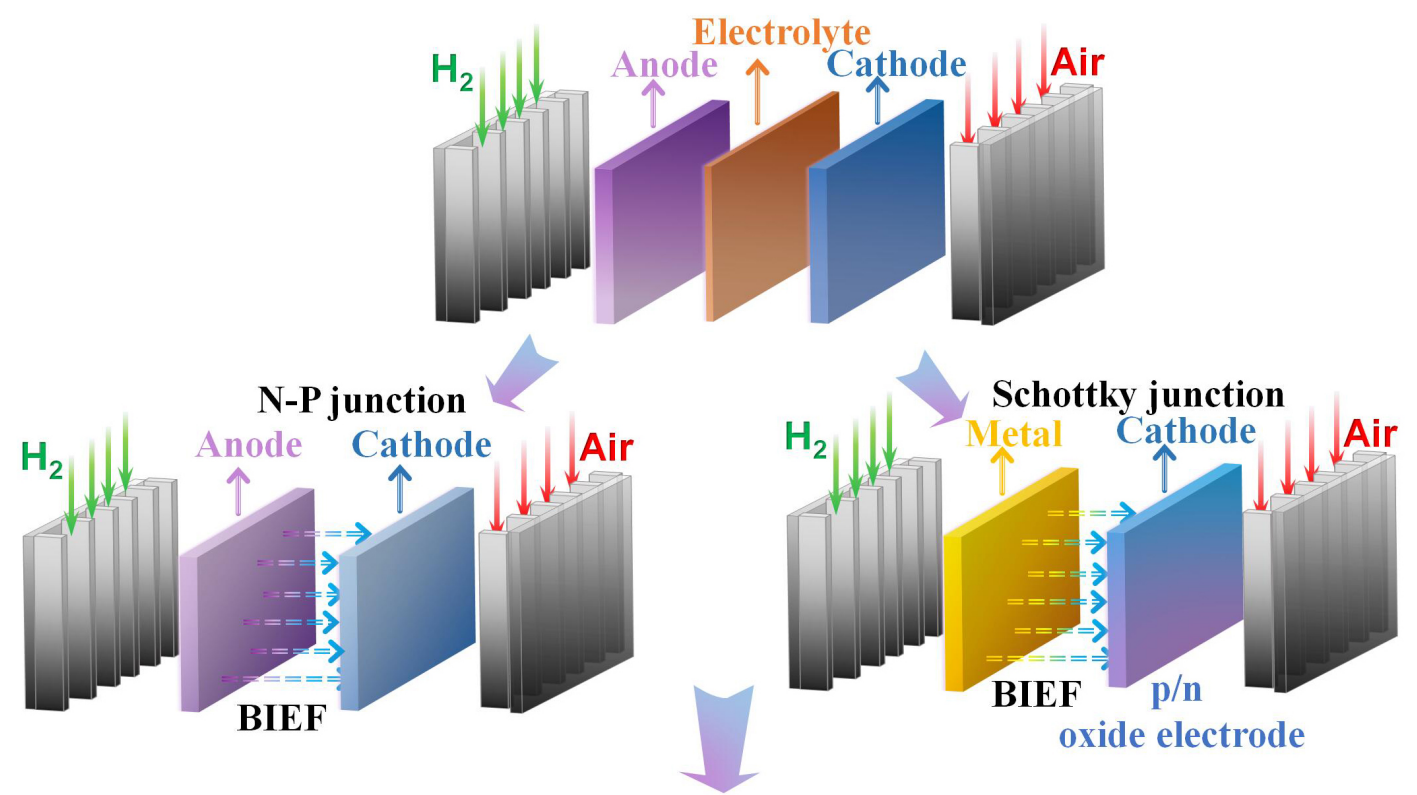

"Three-in-One" membrane

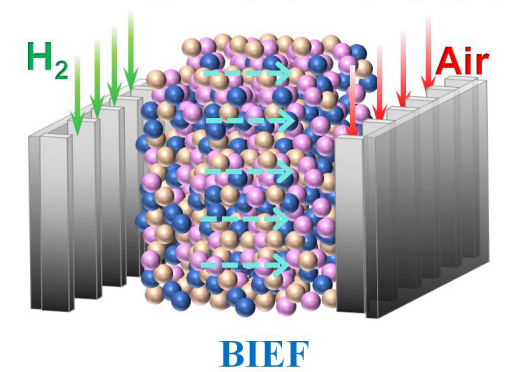

Figure 4. From conventional three layered fuel cells to a "three in one" membrane with a BIEF. BIEF: Built-in electric field.

Cai et al.$^{[32]}$ explained the SIMFC device from the conventional three layers of anode/electrolyte/cathode to a "three in one" membrane, as shown in Figure 4. A semiconductor-ionic membrane based on NiO-yttrium- 
stabilized zirconia (YSZ)-LSCF composites was used to construct a SIMFC device. Under $\mathrm{H}_{2} /$ air conditions, the SJ BIEF is formed that can avoid the electronic short-circuit problem. As a result, A high power density of $680 \mathrm{~mW} \cdot \mathrm{cm}^{-2}$ at $600{ }^{\circ} \mathrm{C}$ was achieved with an open circuit voltage of $1.11 \mathrm{~V}$.

Encouraged by this new concept, Cai et al.$^{[33]}$ further constructed a bulk heterostructure nanocomposite electrolyte of $\mathrm{Ce}_{0.8} \mathrm{Sm}_{0.2} \mathrm{O}_{2-\delta}-\mathrm{SrTiO}_{3}$ for low-temperature SOFCs, exhibiting a peak power density of $892 \mathrm{~mW} \cdot \mathrm{cm}^{-2}$ with an open circuit voltage of $1.1 \mathrm{~V}$ at $550{ }^{\circ} \mathrm{C}$. Generally, SIMFCs are often composted by a semiconductor and ionic conductor, where the heterostructure plays a key role in achieving the high performance. To obtain a deep scientific understanding of SIMFCs, Zhang et al. ${ }^{[34]}$ reviewed superionic conductivity in ceria-based heterostructure composites for low-temperature SOFCs. Hu et al. ${ }^{[35]}$ discussed recent research and development in junctions and energy bands on novel semiconductor-based fuel cells.

Overall, significant progress has been achieved in the field of SIMFCs due to the innovation of semiconductor materials as membranes and advances in forming the BIEF. A high power density of $\sim 1000 \mathrm{~mW} \cdot \mathrm{cm}^{-2}$ at $550{ }^{\circ} \mathrm{C}$ has been achieved from reported SIMFCs with BIEF effects for low-temperature SOFCs. Previous studies on SIMFCs are highlighted in Figure 5.

As shown in Table $1, \mathrm{a} \mathrm{V}_{\text {oc }}$ of $>1.0 \mathrm{~V}$ was individually realized in different heterostructures, suggesting that the performance of devices can be fully improved by the BIEF produced from semiconductor heterostructures. To achieve this goal, the development of high-performance SIMFCs is of significant importance. It is encouraging that the long-term stability of SIMFCs can reach over $100 \mathrm{~h}$, according to recent reports [Table 2]. We believe that the as-reported SIMFCs will provide a new route for SOFC research and development towards commercialization. Compared with traditional SOFCs, SIMFCs exhibit various advantages, e.g., high ionic conductivity resulting in higher performances, including current and power outputs at low temperature, simple structures (three in one) and so on. However, in future research and development, some critical perspectives are suggested:

(1) Long-term stability is currently absent from engineering efforts with regards to commercialization. More effort should be contributed to the engineering and scaling-up of SIMFCs;

(2) In order to develop long-term SIMFC durability, the development of compatible electrode materials has made good progress;

(3) Relevant theoretical models and calculations should be employed to guide further research and development. In particular, the physical properties and effect of the BEIF formed from various heterojunctions, e.g., bulk and planar p-n, Schottky, n-i (intrinsic or insulating) junctions;

(4) Some new technologies and technical processes combined with SOFCs and protonic ceramic fuel cells should be introduced to develop durable SIMFCs.

The first demonstration of SOFC technology was made in the 1930s by Baur and Preis ${ }^{[36]}$ and used zirconia stabilized with $15 \mathrm{wt} . \%$ of yttria (the so-called Nernst Mas) as the electrolyte, iron or carbon as the anode and magnetite $\left(\mathrm{Fe}_{3} \mathrm{O}_{4}\right)$ as the cathode. Long durability could not be achieved until the compatible electrodes, NiO-YSZ cermet and especially perovskite oxide cathode materials, were discovered and technically developed to incorporate with the YSZ electrolyte. This took several decades. Compatible electrodes for semiconductor-ionic material membranes have yet to be employed into SIMFCs. Nevertheless, significant progress has been made in this area. 
Table 2. Long-term stability data for SIMFCs from recent reports

\begin{tabular}{|c|c|c|c|c|c|}
\hline Semiconductor membrane & $\mathbf{v}_{\mathrm{oc}}(\mathbf{V})$ & $\begin{array}{l}\text { Stability } \\
\text { (h) }\end{array}$ & $\begin{array}{l}\text { Temp. } \\
\left({ }^{\circ} \mathrm{C}\right)\end{array}$ & Year & Ref. \\
\hline $\mathrm{La} / \mathrm{Pr}$ co-doped $\mathrm{CeO}_{2}-\mathrm{ZnO}$ & 1.04 & - & 550 & 2018 & [11] \\
\hline $\mathrm{Sm}_{2} \mathrm{O}_{3}-\mathrm{NiO}$ & 1.04 & 2 & 550 & 2018 & [38] \\
\hline $\mathrm{La}_{0.6} \mathrm{Sr}_{0.4} \mathrm{Co}_{0.2} \mathrm{Fe}_{0.8} \mathrm{O}_{3-\delta}-\mathrm{Sm}$ and $\mathrm{Ca}$ co-doped $\mathrm{CeO}_{2}$ & 1.05 & - & 550 & 2019 & {$[7]$} \\
\hline $\mathrm{Mg}$-doped $\mathrm{LiCoO}_{2}$-Sm doped $\mathrm{CeO}_{2}$ & 1.02 & 10 & 600 & 2019 & [39] \\
\hline $\mathrm{CeO}_{2} / \mathrm{CeO}_{2-\delta}$ core-shell structure & 1.04 & - & 520 & 2019 & {$[12]$} \\
\hline $\mathrm{BaCo}_{0.4} \mathrm{Fe}_{0.4} \mathrm{Zr}_{0.1} \mathrm{Y}_{0.1} \mathrm{O}_{3-\delta}-\mathrm{ZnO}$ & 1.01 & $\sim 2$ & 550 & 2020 & [30] \\
\hline $\mathrm{LaNiO}_{3}-\mathrm{Sm}$ doped $\mathrm{CeO}_{2}$ & 1.02 & 52 & 530 & 2020 & [40] \\
\hline $\mathrm{Nb}$-doped $\mathrm{SrTiO}_{3-\delta}$ & 1.03 & - & 520 & 2021 & {$[41]$} \\
\hline $\mathrm{Co}_{0.2} \mathrm{Zn}_{0.8} \mathrm{O}$-Sm-doped $\mathrm{CeO}_{2}$ & 1.06 & 35 & 550 & 2021 & [42] \\
\hline $\mathrm{BaCo}_{0.2} \mathrm{Fe}_{0.1} \mathrm{Ce}_{0.2} \mathrm{Tm}_{0.1}-\mathrm{Zr}_{0.3} \mathrm{Y}_{0.1} \mathrm{O}_{3-\delta}$ & 1.07 & 100 & 530 & 2021 & [43] \\
\hline $\mathrm{BaSrFeSbO}_{3}-\mathrm{Sm}$ doped $\mathrm{CeO}_{2}$ & 1.09 & 100 & 550 & 2021 & [31] \\
\hline
\end{tabular}

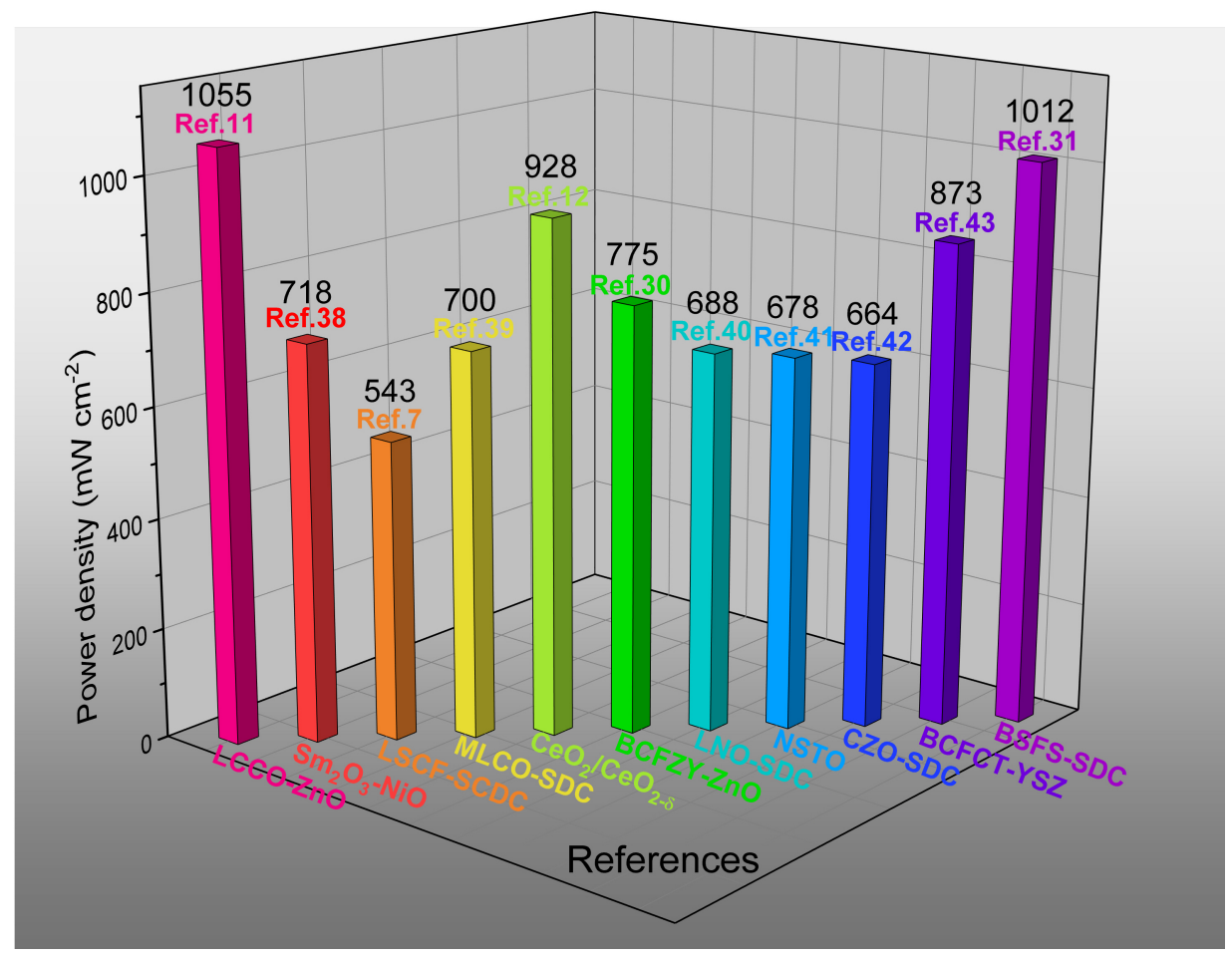

Figure 5. Summary of previous work on SIMFCs. LCCO-ZnO: La/Pr co-doped $\mathrm{CeO}_{2}-\mathrm{ZnO}$; LSCF-SCDC: $\mathrm{La}_{0.6} \mathrm{Sr}_{0.4} \mathrm{Co}_{0.2} \mathrm{Fe}_{0.8} \mathrm{O}_{3-\delta}-\mathrm{Sm}$ and $\mathrm{Ca}$ co-doped $\mathrm{CeO}_{2} ; \mathrm{MLCO}-\mathrm{SDC}$ : Mg-doped $\mathrm{LiCoO}_{2}$-Sm doped $\mathrm{CeO}_{2} ; \mathrm{CeO}_{2} / \mathrm{CeO}_{2-\delta}$ : the core hall structure of the $\mathrm{CeO}_{2} / \mathrm{CeO}_{2-\delta ;} ; \mathrm{BCFZY}^{-}$ $\mathrm{ZnO}: \mathrm{BaCo}_{0.4} \mathrm{Fe}_{0.4} \mathrm{Zr}_{0.1} \mathrm{Y}_{0.1} \mathrm{O}_{3-\delta}-\mathrm{ZnO}$; LNO-SDC: LaNiO $-\mathrm{Sm}$ doped $\mathrm{CeO}_{2} ;$ NSTO: Nb-doped $\mathrm{SrTiO}_{3-\delta} ; \mathrm{CZO}-\mathrm{SDC}: \mathrm{Co}_{0.2} \mathrm{Zn}_{0.8} \mathrm{O}-\mathrm{Sm}_{-}$-doped $\mathrm{CeO}_{2} ;$ BCFCT-YSZ: $\mathrm{BaCO}_{0.2} \mathrm{Fe}_{0.1} \mathrm{Ce}_{0.2} \mathrm{Tm}_{0.1}-\mathrm{Zr}_{0.3} \mathrm{Y}_{0.1} \mathrm{O}_{3-\delta ;}$ BSFS-SDC: $\mathrm{BaSrFeSbO}_{3}-\mathrm{Sm}$ doped $\mathrm{CeO}_{2}$.

It is also noteworthy that SIMFCs are built not only on electrochemistry but also semiconductor physics ${ }^{[37]}$. We expect that this report can arouse significant attention from related research fields and disciplines to overcome the bottleneck of SOFC commercialization.

\section{DECLARATIONS}

\section{Acknowledgments}

This work was supported by Southeast University (SEU) Solar Energy and Joint Energy Storage Center, 
Functional Materials Laboratory (FML), Xi'an University of Architecture and Technology (XAUAT), and Laboratory of Functional materials and device, Nanjing Xiaozhuang University.

\section{Authors' contributions}

Made substantial contributions to conception and design of this Research Highlight: Yun S, Zhu B

Investigation, formal analysis, writing - original draft: Lu Y

Data curation: Shi J

Supervision, methodology, resources, visualization, funding acquisition, project administration, writing review \& editing: Yun S, Zhu B

\section{Availability of data and materials}

Not applicable.

\section{Financial support and sponsorship}

This work was supported by NSFC (No. 51672208, 51772080), Key Program for International S\&T Cooperation Projects of Shaanxi Province (No. 2019KWZ-03, No. 2019JZ-20), and Open foundation Project of key Laboratory of Plateau Green Building and Ecological Community of Qinghai Province (No. KLKF2019-002) is greatly acknowledged. This research was also funded by the Foundation of Nanjing Xiaozhuang University (Grant No. 2020NXY12).

\section{Conflicts of interest}

All authors declared that there are no conflicts of interest.

\section{Ethical approval and consent to participate}

Not applicable.

\section{Consent for publication}

Not applicable.

\section{Copyright}

(c) The Author(s) 2021.

\section{REFERENCES}

1. Fan L, Zhu B, Su P, He C. Nanomaterials and technologies for low temperature solid oxide fuel cells: recent advances, challenges and opportunities. Nano Energy 2018;45:148-76. DOI

2. Zhang Y, Knibbe R, Sunarso J, et al. Recent progress on advanced materials for solid-oxide fuel cells operating below $500{ }^{\circ} \mathrm{C}$. $A d v$ Mater 2017;29:1700132. DOI PubMed

3. Meng Y, Mi Y, Xu F, et al. Low-temperature fuel cells using a composite of redox-stable perovskite oxide $\mathrm{La}_{0.7} \mathrm{Sr}_{0.3} \mathrm{Cr}_{0.5} \mathrm{Fe}_{0.5} \mathrm{O}_{3-\delta}$ and ionic conductor. J Power Sources 2017;366:259-64. DOI

4. Li J, Lu Y, Li D, Qi F, Yu L, Xia C. Effects of P-N and N-N heterostructures and band alignment on the performance of lowtemperature solid oxide fuel cells. Int J Hydrogen Energy 2021;46:9790-8. DOI

5. Wang B, Wang Y, Fan L, et al. Preparation and characterization of Sm and Ca co-doped ceria- $\mathrm{La}_{0.6} \mathrm{Sr}_{0.4} \mathrm{Co}_{0.2} \mathrm{Fe}_{0.8} \mathrm{O}_{3-\delta}$ semiconductorionic composites for electrolyte-layer-free fuel cells. J Mater Chem A 2016;4:15426-36. DOI

6. Zhang W, Cai Y, Wang B, et al. The fuel cells studies from ionic electrolyte $\mathrm{Ce}_{0.8} \mathrm{Sm}_{0.05} \mathrm{Ca}_{0.15} \mathrm{O}_{2-\delta}$ to the mixture layers with semiconductor $\mathrm{Ni}_{0.8} \mathrm{Co}_{0.15} \mathrm{Al}_{0.05} \mathrm{LiO}_{2-\delta}$. Int $J$ Hydrogen Energy 2016;41:18761-8. DOI

7. Nie X, Chen Y, Mushtaq N, et al. The sintering temperature effect on electrochemical properties of $\mathrm{Ce}_{0.8} \mathrm{Sm}_{0.05} \mathrm{Ca}_{0.15} \mathrm{O}_{2-\delta}\left(\mathrm{SCDC}_{\mathrm{C}}\right)-\mathrm{La}{ }_{0.6}$ $\mathrm{Sr}_{0.4} \mathrm{Co}_{0.2} \mathrm{Fe}_{0.8} \mathrm{O}_{3-\delta}$ (LSCF) heterostructure pellet. Nanoscale Res Lett 2019;14:162. DOI PubMed PMC

8. Deng H, Feng C, Zhang W, et al. The electrolyte-layer free fuel cell using a semiconductor-ionic $\mathrm{Sr}_{2} \mathrm{Fe}_{1.5} \mathrm{Mo}_{0.5} \mathrm{O}_{6-\delta}-\mathrm{Ce}_{0.8} \mathrm{Sm}_{0.2} \mathrm{O}_{2-\delta}$ composite functional membrane. Int J Hydrogen Energy 2017;42:25001-7. DOI

9. Mushtaq N, Xia C, Dong W, et al. Tuning the energy band structure at interfaces of the $\mathrm{SrFe}_{0.75} \mathrm{Ti}_{0.25} \mathrm{O}_{3-\delta}-\mathrm{Sm}_{0.25} \mathrm{Ce}_{0.75} \mathrm{O}_{2-\delta}$ heterostructure for fast ionic transport. ACS Appl Mater Interfaces 2019;11:38737-45. DOI PubMed

10. Afzal M, Saleemi M, Wang B, et al. Fabrication of novel electrolyte-layer free fuel cell with semi-ionic conductor $\left(\mathrm{Ba}_{0.5} \mathrm{Sr}_{0.5} \mathrm{Co}_{0.8} \mathrm{Fe}_{0.2}\right.$ $\mathrm{O}_{3-\delta}-\mathrm{Sm}_{0.2} \mathrm{Ce}_{0.8} \mathrm{O}_{1.9}$ ) and Schottky barrier. J Power Sources 2016;328:136-42. DOI

11. Shah M, Mushtaq N, Rauf S, Xia C, Zhu B. The semiconductor $\mathrm{SrFe}_{0.2} \mathrm{Ti}_{0.8} \mathrm{O}_{3-\delta}-\mathrm{ZnO}$ hetero-structure electrolyte fuel cells. Int $J$ 
Hydrog Energy 2019;44:30319-27. DOI

12. Xing $\mathrm{Y}, \mathrm{Wu} \mathrm{Y}$, $\mathrm{Li}$ L, et al. Proton shuttles in $\mathrm{CeO}_{2} / \mathrm{CeO}_{2-\delta}$ core-shell structure. ACS Energy Lett 2019;4:2601-7. DOI

13. Chen G, Liu H, He Y, et al. Electrochemical mechanisms of an advanced low-temperature fuel cell with a $\mathrm{SrTiO}_{3}$ electrolyte. $J$ Mater Chem A 2019;7:9638-45. DOI

14. Islam QA, Paydar S, Akbar N, Zhu B, Wu Y. Nanoparticle exsolution in perovskite oxide and its sustainable electrochemical energy systems. J Power Sources 2021;492:229626. DOI

15. Zhu B, Lund P, Raza R, et al. A new energy conversion technology based on nano-redox and nano-device processes. Nano Energy 2013;2:1179-85. DOI

16. Zhu B, Huang Y, Fan L, et al. Novel fuel cell with nanocomposite functional layer designed by perovskite solar cell principle. Nano Energy 2016;19:156-64. DOI

17. Zhu B, Raza R, Liu Q, et al. A new energy conversion technology joining electrochemical and physical principles. $R S C A d v$ 2012;2:5066. DOI

18. Wang F, Xing Y, Hu E, et al. PN heterostructure interface-facilitated proton conduction in $3 \mathrm{C}-\mathrm{SiC} / \mathrm{Na}_{0.6} \mathrm{CoO}_{2}$ electrolyte for fuel cell application. ACS Appl Energy Mater 2021;4:7519-25. DOI

19. Lu Y, Mi Y, Li J, Qi F, Yan S, Dong W. Recent progress in semiconductor-ionic conductor nanomaterial as a membrane for lowtemperature solid oxide fuel cells. Nanomaterials (Basel) 2021;11:2290. DOI PubMed PMC

20. Xu D, Yan A, Xu S, et al. Self-Assembled Triple $\left(\mathrm{H}^{+} / \mathrm{O}^{2-} / \mathrm{e}^{-}\right)$conducting nanocomposite of Ba-Co-Ce-Y-O into an electrolyte for semiconductor ionic fuel cells. Nanomaterials (Basel) 2021;11:2365. DOI PubMed PMC

21. Zhu B, Mi Y, Xia C, et al. Nano-scale view into solid oxide fuel cell and semiconductor membrane fuel cell: material and technology. Energy Mater 2021;1:2. DOI

22. Fang Y, Dong Q, Shao Y, Yuan Y, Huang J. Highly narrowband perovskite single-crystal photodetectors enabled by surface-charge recombination. Nature Photon 2015;9:679-86. DOI

23. Assadi M, Bakhoda S, Saidur R, Hanaei H. Recent progress in perovskite solar cells. Renew Sustain Energy Rev 2018;81:2812-22. DOI

24. Choi S, Kucharczyk CJ, Liang Y, et al. Exceptional power density and stability at intermediate temperatures in protonic ceramic fuel cells. Nat Energy 2018;3:202-10. DOI

25. Qiao Z, Xia C, Cai Y, et al. Electrochemical and electrical properties of doped $\mathrm{CeO}_{2}-\mathrm{ZnO}$ composite for low-temperature solid oxide fuel cell applications. J Power Sources 2018;392:33-40. DOI

26. Wang L, Xie R, Chen B, et al. In-situ visualization of the space-charge-layer effect on interfacial lithium-ion transport in all-solid-state batteries. Nat Commun 2020;11:5889. DOI PubMed PMC

27. Yun S, Qin Y, Uhl AR, et al. New-generation integrated devices based on dye-sensitized and perovskite solar cells. Energy Environ Sci 2018;11:476-526. DOI

28. Yun $\mathrm{S}$, Zhou X, Even J, Hagfeldt A. Theoretical treatment of $\mathrm{CH}_{3} \mathrm{NH}_{3} \mathrm{PbI}_{3}$ perovskite solar cells. Angew Chem Int Ed Engl 2017;56:15806-17. DOI

29. Zhu B, Lund PD, Raza R, et al. Schottky junction effect on high performance fuel cells based on nanocomposite materials. Adv Energy Mater 2015;5:1401895. DOI

30. Xia C, Mi Y, Wang B, Lin B, Chen G, Zhu B. Shaping triple-conducting semiconductor $\mathrm{BaCo}_{0.4} \mathrm{Fe}_{0.4} \mathrm{Zr}_{0.1} \mathrm{Y}_{0.1} \mathrm{O}_{3-\delta}$ into an electrolyte for low-temperature solid oxide fuel cells. Nat Commun 2019;10:1707. DOI PubMed PMC

31. Mushtaq N, Lu YZ, Xia C, et al. Promoted electrocatalytic activity and ionic transport simultaneously in dual functional $\mathrm{Ba}_{0.5} \mathrm{Sr}_{0.5} \mathrm{Fe}_{0.8}$ $\mathrm{Sb}_{0.2} \mathrm{O}_{3-\delta}-\mathrm{Sm}_{0.2} \mathrm{Ce}_{0.8} \mathrm{O}_{2-\delta}$ heterostructure. Applied Catalysis B: Environmental 2021;298:120503. DOI

32. Cai Y, Wang B, Wang Y, et al. Validating the technological feasibility of yttria-stabilized zirconia-based semiconducting-ionic composite in intermediate-temperature solid oxide fuel cells. J Power Sources 2018;384:318-27. DOI

33. Cai Y, Chen Y, Akbar M, et al. A bulk-heterostructure nanocomposite electrolyte of $\mathrm{Ce}_{0.8} \mathrm{Sm}_{0.2} \mathrm{O}_{2-\delta}-\mathrm{SrTiO}_{3}$ for low-temperature solid oxide fuel cells. Nanomicro Lett 2021;13:46. DOI PubMed PMC

34. Zhang Y, Liu J, Singh M, et al. Superionic conductivity in ceria-based heterostructure composites for low-temperature solid oxide fuel cells. Nanomicro Lett 2020;12:178. DOI PubMed PMC

35. Hu E, Jiang Z, Fan L, et al. Junction and energy band on novel semiconductor-based fuel cells. iScience 2021;24:102191. DOI PubMed PMC

36. Baur E, Preis H. Über brennstoff-ketten mit festleitern. Elektrochem 1937;43:727-32. DOI

37. Zhu B, Fan L, Mushtaq N, et al. Semiconductor electrochemistry for clean energy conversion and storage. Electrochemical Energy Reviews 2021. DOI

38. Liu L, Liu Y, Li L, Wu Y, Singh M, Zhu B. The composite electrolyte with an insulation $\mathrm{Sm}_{2} \mathrm{O}_{3}$ and semiconductor NiO for advanced fuel cells. Int J Hydrogen energy Energy 2018;43:12739-47. DOI

39. Ganesh KS, Wang B, Kim J, Zhu B. Ionic conducting properties and fuel cell performance developed by band structures. J Phys Chem C 2019;123:8569-77. DOI

40. Lu Y, Akbar M, Xia C, et al. Catalytic membrane with high ion-electron conduction made of strongly correlated perovskite $\mathrm{LaNiO}_{3}$ and $\mathrm{Ce}_{0.8} \mathrm{Sm}_{0.2} \mathrm{O}_{2-\delta}$ for fuel cells. Journal of Catalysis 2020;386:117-25. DOI

41. Shah MAKY, Rauf S, Zhu B, et al. Semiconductor Nb-doped $\mathrm{SrTiO}_{3-\delta}$ perovskite electrolyte for a ceramic fuel cell. ACS Appl Energy Mater 2021;4:365-75. DOI

42. Rauf S, Shah MAKY, Zhu B, et al. Electrochemical properties of a dual-ion semiconductor-ionic $\mathrm{Co}_{0.2} \mathrm{Zn}_{0.8} \mathrm{O}-\mathrm{Sm}_{0.20} \mathrm{Ce}_{0.80} \mathrm{O}_{2-\delta}$ composite for a high-performance low-temperature solid oxide fuel cell. ACS Appl Energy Mater 2021;4:194-207. DOI 
43. Rauf $\mathrm{S}$, Zhu B, Shah MY, et al. Tailoring triple charge conduction in $\mathrm{BaCo}_{0.2} \mathrm{Fe}_{0.1} \mathrm{Ce}_{0.2} \mathrm{Tm}_{0.1} \mathrm{Zr}_{0.3} \mathrm{Y}_{0.1} \mathrm{O}_{3-\delta}$ semiconductor electrolyte for boosting solid oxide fuel cell performance. Renewable Energy 2021;172:336-49. DOI 